FRANÇOIS GRIN and BRITTA KORTH

\title{
ON THE RECIPROCAL INFLUENCE OF LANGUAGE POLITICS AND LANGUAGE EDUCATION: THE CASE OF ENGLISH IN SWITZERLAND
}

(Received 12 April 2004; accepted in revised form 18 August 2004)

\begin{abstract}
Linguistic diversity in Switzerland, which is generally regarded as a successful case of language management, is currently being challenged. One of the most significant reasons for this is the growing importance of English. While national languages were traditionally taught as the first foreign language and English as the second foreign language throughout Switzerland, English has gained in importance, leading, in some cantons, to its earlier introduction, or/and more hours of English in the curriculum. This paper reviews these issues, taking the historical roots and institutional aspects of Swiss multilingualism into account. Current developments in language education are analysed not just as pedagogical, put as political and policy responses to the major challenges confronting the longstanding principles of diversity management in Switzerland.
\end{abstract}

KEY WORDS: bilingual education, English teaching, language awareness, language policy, language teaching, linguistic diversity, Switzerland

ABBREVIATIONS: CDIP-EDK - Standing Conference of Cantonal Education Ministers; CLIL - Content and Language Integrated Learning; FL - Foreign Language; ILC - Integrated Language Concept

\section{INTRODUCTION}

Scholars regularly quote Switzerland as a successful example of management of linguistic diversity. However, despite this flattering attention, Switzerland remains a relatively little-known, sometimes even misunderstood case, and it often proves useful not only to explain the intricacies of Switzerland's language arrangement, but also to call attention to the challenges that the country has to face in language politics and language policy.

This paper addresses this twin set of questions. At the same time, it explores the dynamics that shape the reciprocal relationships between macro-level language politics and language issues on the one hand, and one specific language education issue on the other hand, namely, the teaching of English as a foreign language. 
No proper account of the Swiss case can dispense with a review of the historical roots of Swiss multilingualism and an analysis of its political and institutional implications. These dimensions are discussed in the next section, providing a backdrop for our overview, in the following section, of current provisions for foreign language teaching in the education system across Switzerland. Subsequent sections turn to the particular case of English and to the assessment of the related policy implications and public debate. The last section reviews two pedagogical responses to language politics challenges. The main points of this paper are summarised in a short conclusion.

\section{Institutional Setting And Historical Roots}

Until the end of the 18th century, the relatively loose confederation of micro-states that was then Switzerland operated in German, despite the fact that some cantons ruled neighbouring communities (traditionally called "bailiwicks") in which German, French, Italian, or Romantsch were used. The Napoleonic wars, at the turn of the 19th century, eliminated these Ancien Régime structures; former bailiwicks were elevated to the rank of full-fledged cantons; additional, long independent micro-states like Geneva also joined the confederation, and Switzerland stabilised within its current borders in 1815.

Switzerland thus became a quadrilingual country whose citizens could be native speakers of German (usually in the form of an Alemannic dialect), French, Italian, or Romantsch. This pluralism was regarded as an anomaly at a time when the ideology of the unitary nation-state (one people, one language, one nation, one state) was holding sway. In addition, Switzerland was the only republic in a Europe of monarchies. The political and cultural discourse on Switzerland as a Willensnation (nation of the will) defined by its very diversity was therefore developed in this period to legitimise this pluralism (Froidevaux, 1997; Grin, 2002). The country's first modern constitution, in 1848, mentioned three national and official languages (German, French, and Italian); this provision was confirmed in the 1874 Constitution. Amendments in 1938 and 1996 gave Romantsch recognition as an additional national language. In the present Constitution (in force since 2000), all four languages are considered "national"; German, French, and Italian, in addition, are "official," while Romantsch is also official, but only "for the purposes of communication between the Federal government and Romantschspeaking citizens." 
Federal provisions regarding language account for only one part of Switzerland's linguistic arrangement, and perhaps not the most important one. Switzerland remains a truly federalist country, where sovereignty rests with the cantons. There are 23 cantons of which 3 , for historical reasons not discussed here, are split in "half-cantons"; it is therefore an acceptable shortcut to say that Switzerland comprises 26 cantons. These micro-states delegate competencies to the federal government, making Switzerland a case of devolution in reverse. Powers handed over to the federal government include, for example, national defence, energy supply, highways, and some parts of the social insurance system; however, language policy and education are among the competencies that the cantons have retained. Therefore, it would be deeply mistaken to view Switzerland as a country in which a majority (the speakers of German) "concedes" some kind of "autonomy" to minorities (speakers of French, Italian, and Romantsch). Even more erroneous would be the notion that speakers of French are actually a "nation" for whom France is "the kin state," or that speakers of German are "in fact" Germans ${ }^{1}$ (see Grin, 2002).

Another key factor in Switzerland's language situation is the use of the territoriality principle, according to which each point in the national territory (with a few exceptions) has one and only one locally official language. Whereas most cantons are defined as monolingual, three (Fribourg/Freiburg, Valais/Wallis and Bern/Berne) are bilingual (French and German) and one (Graubünden/Grischun/Grigioni) is trilingual (German, Romantsch and Italian). In the three bilingual cantons, the language boundary runs right through the canton, and public services are available, either side of it, in one language only (German or French). A few municipalities are designated as bilingual, but they constitute exceptions. In geolinguistic terms, language boundaries have remained practically unchanged for some seven centuries (Haas, 1985/2000). The situation in the trilingual canton is even more complex, since in this case, the cantonal authorities have devolved to municipalities the responsibility to choose their own

\footnotetext{
${ }^{1}$ Also note that linguistic boundaries and (inter-cantonal) political boundaries do not coincide, and that religion is not correlated with language either. The two main religions in the country, Calvinist Protestantism and Roman Catholicism, are symmetrically represented in the German, French, and Romantsch-speaking communities. Only the Italian-speaking community is predominantly (though not systematically) associated with one religion (Roman Catholicism). Given the deeply secularised character of modern Switzerland, religious affiliation is of no consequence. However, this is a relevant aspect of what is often referred to as Switzerland's "cross-cutting cleavages."
} 
official language; this arrangement has proved notoriously unstable, and is often seen as a contributing factor to the demolinguistic decline of Romantsch.

The rather intricate Swiss pattern is further complicated by the presence of a sizeable immigrant population. With foreigners making up about $20 \%$ of the resident population, Switzerland has the second highest rate in Europe after Luxembourg (apart from very small states like Andorra or Monaco). Nine percent of the resident population claims a main language other than any of the four national languages. The distribution of the population by main language spoken is provided in Table 1.

According to a common belief abroad, the average Swiss person is multilingual. However, the reality is quite different. Survey results indicate that $97 \%$ report one (and only one) mother tongue. Competence in additional languages, national or other, is of course widespread, but unevenly distributed. Generally, the level of skills in other languages is higher in the smaller language communities. Speakers of Romantsch are also fluent in German and speakers of Italian tend to have high competence in French and/or German ${ }^{2}$ (Grin, 1999).

The case of the German-speaking parts of the country deserves additional commentary, owing to diglossia between standard

TABLE 1

Population by main language, percentages, 2000.

\begin{tabular}{lcc}
\hline & $\begin{array}{c}\text { Resident population } \\
N=7,280,000\end{array}$ & $\begin{array}{c}\text { Swiss citizens only } \\
N=5,792,459\end{array}$ \\
\hline German $^{\mathrm{a}}$ & 63.7 & 72.5 \\
French $^{\mathrm{a}}$ & 20.4 & 21.0 \\
Italian $^{\mathrm{a}}$ & 6.5 & 4.3 \\
Serbo-Croatian $_{\text {Albanian }}$ & 1.4 & 0.1 \\
Portuguese & 1.3 & 0.0 \\
Spanish & 1.2 & 0.1 \\
English & 1.1 & 0.2 \\
Turkish & 1.0 & 0.4 \\
Romantsch & 0.6 & 0.1 \\
Others & 0.5 & 0.6 \\
\hline
\end{tabular}

${ }^{\text {a National language. }}$

Source: Office fédéral de la statistique (2002).

\footnotetext{
${ }^{2}$ For detailed survey results including skills levels in second or foreign languages, (see Grin, 1999). The decennial censuses include questions on a person's "first language" and patterns of language use, but does not record language skills.
} 
German and one of the many local forms of Swiss German. Swiss German is markedly different from standard German, and even native speakers of German coming from Germany (apart the neighbouring southwestern parts of the country) only understand it with great difficulty. Far from declining, the use of dialect is spreading, and it is not restricted to given socio-economic segments of the population. It is used as the regular medium of spoken communication in much of public life, including many television and radio programmes. The lack of a written standard is probably what prevents its spread to non-oral domains.

Against this highly complex demolinguistic, sociolinguistic, political, and institutional background, the search for suitable language education policies is an arduous one. The rising influence of English further complicates the picture. In the following section, we discuss the resulting challenges and their role in public debate and language education policy.

\section{Foreign Languages in the Swiss Education System ${ }^{3}$}

Education is a matter of cantonal competence in Switzerland. ${ }^{4}$ Nevertheless, the Standing Conference of Cantonal Education Ministers (CDIP-EDK) regularly issues recommendations on various aspects of the curriculum, and educational goals, including on foreign language education, which are endorsed by the 26 cantons.

One recommendation, adopted in 1975, held that the teaching of a national language should be compulsory (Grin, Hexel \& Schwob, 2003: 91). In practice, this generally meant that French was taught as the first foreign language (FL) in the German-speaking and Italianspeaking parts of the country, while German was taught as the first FL in the French-speaking part. Traditionally, Italian was offered in the French- and German-speaking regions as an elective FL, usually in post-compulsory education (that is, only from the age of 15).

\footnotetext{
${ }^{3}$ The expression "foreign" language is used here to denote any language other than the locally official national language, even if it may be an official language elsewhere in the country; for a more detailed discussion, see e.g. Grin and Schwob (2002).

${ }^{4}$ The language of instruction in the 26 public education systems is always the locally official language. There is no right, for example, to French-medium education in Zurich or to German-medium education in Geneva. Private schools may teach through other languages, but the Federal Supreme Court has upheld the Cantons' right to restrict access to such private schools, on the grounds that the principle of territoriality might otherwise be undermined. Recent developments, however, indicate a more relaxed attitude towards territoriality.
} 
However, Italian was offered as a second FL at an earlier age, in specific streams, at "Secondary I" level, namely, from ages 12/13 to $15 / 16$. In the same way, English used to be a compulsory subject as a second FL only after the age of 15 , for students intending to go on to tertiary (university) education; like Italian, however, English was offered at an earlier age in specific streams at Secondary I level. Since only a minority of students attended pre-university streams, a majority of each cohort received no English at all, and this situation by and large prevailed until the 1990s.

Given the disappointing FL skills levels achieved by students, a major reform, implemented in all cantons but one in the early 1980s, was the earlier introduction of first FL instruction. However, broad segments of public opinion expressed concern over access to competence in English, whose spread, abetted by a wider process of globalisation, made it an increasingly important element of a person's human capital. Some cantons started introducing English as a compulsory subject, and some even did so at primary school. Thus, English as an FL entered in competition with Switzerland's national languages, giving rise to tensions that have sharpened in recent years.

In 1998, a committee of experts commissioned by the CDIP-EDK delivered an Integrated Language Concept, hereafter ILC (CDIP/ EDK, 1998). The committee's report did not amount to a formal recommendation. It did, however, signal a departure from the earlier arrangement, in that it implicitly left cantons a choice regarding the order in which a national language and English would be introduced in the curriculum. The only restrictions were that one national language should be among the foreign languages that children learn at school, and that the competence level reached in this language should not be less than the competence level reached in other foreign languages (that is, in English). Thus, the committee abstained from advocating regulation of the input in the process, arguing instead that what really mattered was the output. Given the eminently complex (and often loose) relationship in foreign language education between inputs (in particular hours of instruction) and outputs (FL competence), the ILC has been widely interpreted as permission to cantons to handle the question much as they pleased.

At the time of writing (March 2004), the tendencies described above have deepened. The CDIP-EDK (2001b) keeps stressing the importance of foreign language acquisition; it recommends that binding learning aims for the end of the sixth and ninth school year be defined, without specifying the age and order of introduction of foreign languages. The French- and Italian-speaking cantons within 
TABLE 2

L2 and L3 teaching in compulsory primary and secondary education selected cantons. 2003-2004 schoolyear.

\begin{tabular}{|c|c|c|c|c|c|c|c|c|c|}
\hline $\begin{array}{l}\text { Canton } \\
\text { Locally } \\
\text { official } \\
\text { language }\end{array}$ & & \multicolumn{2}{|c|}{$\begin{array}{l}\text { Geneva } \\
\text { French }\end{array}$} & \multicolumn{3}{|c|}{$\begin{array}{l}\text { Zurich } \\
\text { German }\end{array}$} & & \multicolumn{2}{|c|}{$\begin{array}{l}\text { Ticino }^{\mathrm{b}} \\
\text { Italian }\end{array}$} \\
\hline $\begin{array}{l}\text { Grade } \downarrow \\
1 \\
2 \\
3 \\
4 \\
5 \\
6 \\
7 \\
8 \\
9\end{array}$ & & $\begin{array}{r}- \\
- \\
\mathrm{G} \\
\mathrm{G} \\
\mathrm{G} \\
\mathrm{G} \\
\mathrm{G}+ \\
\mathrm{G}+ \\
\mathrm{G}+\end{array}$ & & & & $\begin{array}{l}\text { E } \\
\text { E } \\
\text { E }\end{array}$ & & $\begin{array}{r}\mathrm{F} \\
\mathrm{F} \\
\mathrm{F} \\
\mathrm{F} \\
\mathrm{F}+ \\
\mathrm{F}+ \\
\mathrm{G}+ \\
\mathrm{F}+ \\
\mathrm{G}+\end{array}$ & \\
\hline $10-13^{\mathrm{a}}$ & $\begin{array}{l}\mathrm{L} 2 \\
\mathrm{G} \\
\text { or E }\end{array}$ & $\begin{array}{l}\text { L3 } \\
\text { G. E } \\
\text { or S }\end{array}$ & $\begin{array}{l}\text { L4 } \\
\text { g. e } \\
\text { or s }\end{array}$ & $\begin{array}{l}\text { L2 } \\
\text { F } \\
\text { or I }\end{array}$ & $\begin{array}{l}\text { L3 } \\
\text { F. I } \\
\text { or E }\end{array}$ & $\begin{array}{l}\text { L4 } \\
\text { e. f. I. s } \\
\text { or r }\end{array}$ & $\begin{array}{l}\mathrm{L} 2 \\
\mathrm{G} \\
\text { or F }\end{array}$ & $\begin{array}{l}\text { L3 } \\
\text { F. G } \\
\text { or E }\end{array}$ & $\begin{array}{l}\text { L4 } \\
\text { g. } f \\
\text { or e }\end{array}$ \\
\hline
\end{tabular}

Key: G. g: German; F. f: French; E. e: English. I. i: Italian; S. s: Spanish; R. r: Russian. Uppercase: compulsory; lowercase: elective. Classical languages (Latin, Ancient Greek) not included.

${ }^{a}$ One national language is compulsory as an L2. One additional foreign language is compulsory, but it does not have to be a national language. Students may choose more than one additional foreign language; the maximum number of foreign languages that students may study during post-secondary education (secondary II) level (Grades 10 through 13) is four in Zurich and Ticino, three in Geneva.

${ }^{\mathrm{b}}$ From 2004-2005 school year.

the CDIP-EDK generally recommend teaching a national language as an FL from the 3rd grade on, while the introduction of English is recommended in 7th grade (CIIP, 2003). The latest decision by the CDIP, issued on 31 March 2004 (http://www.edk.ch/PDF Downloads/Presse/PM_Sprachen_f.pdf), recommends the introduction of two foreign languages at primary school (one in Grade 3, the other at Grade 5). However, this system is only supposed to be fully implemented by 2012, and in the transition period, the introduction of the second foreign language can be deferred until Grade 7 unless the first foreign language introduced is not a national language. 
Current provisions for first and second FL instruction in three selected Swiss cantons are summarised in Table 2.

Overall, the extent of instruction that Swiss children receive in foreign languages varies greatly. Part of the variability is linked to the fact that some language subjects are compulsory while others are elective. It also reflects the fragmentation of the system, since the number of periods in the weekly schedule during which a language is taught, as well as the various pedagogical practices and materials, is set independently by the cantons, and is therefore heterogeneous. ${ }^{5}$

\section{ENGLISH IN SWITZERLAND}

The importance of compulsory English itself is generally not questioned (Acklin Muji 2003: 68), but public opinion, while overwhelmingly in favour of developing access to English for all children in the education system, is torn over the position that national languages should have in the curriculum: Should it be given more or less importance than English, or should they be on par?

Despite a flurry of publications on various aspects of the issue (e.g. Watts \& Murray 2001; Acklin Muji 2003; Stotz \& Meuter 2003), "hard" data, in the sense of an adequate number of observations from representative samples remain few. As to census data, their coverage of language variables remains limited. All this makes it difficult to provide a complete and balanced account. Our assessment therefore refers to small-scale evaluations of pilot projects as well as qualitative studies.

\section{Language Learning and Attitudes}

An evaluation report of obligatory English teaching in Zurich (Moser, Rhyn \& Stamm, 2002: 21-25) shows that out of 3,966 German-speaking 7th- and 8th-graders who had learned French as a second FL and English as a third FL, a majority are more interested in learning English than French; they feel more confident about their skills in English and would prefer English over French, if given a choice between the two. English is also often seen as the foreign language that most of the Swiss will soon master better than any other language (Aeberli, 2001: 84).

A sociolinguistic study among 1,351 German learners between the ages of 11 and 18 shows that attitudes towards German and German-

\footnotetext{
${ }^{5}$ Information on language teaching in schools in the different Swiss cantons can be found at: http://www.ides.ch/umfrage2003/mainUmfrage_D.html.
} 
TABLE 3

Preferred language of communication

with members of other language communities, by region, in percentages.

\begin{tabular}{lcc}
\hline & $\begin{array}{l}\text { French-speaking } \\
\text { Switzerland }\end{array}$ & $\begin{array}{l}\text { German-speaking } \\
\text { Switzerland }\end{array}$ \\
\hline English & 28 & 27 \\
French & 23 & 17 \\
German & 18 & 22 \\
\hline
\end{tabular}

Source: Murray et al. (2000: 17).

language learning are more negative among young French-speaking Swiss than among their peers in Bulgaria and France (de Pietro, 1994). French and Italian speakers are concerned that the standard German they are taught at school as an L2 may be of little use for interacting with the German-speaking Swiss, who tend to feel uncomfortable with standard German (which is often perceived as pompous) and prefer to use an Alemannic dialect (Ogay, 2000: 144). As a result, there is a widespread perception that many people in German-speaking Switzerland prefer to switch to English instead of standard German when communicating with French- or Italianspeaking fellow Swiss.

Casual observation suggests that the motivation to use and apply English-language skills (whether these have been acquired in daily life or in a formal school setting) will tend to be higher than the motivation to do the same for national languages. An opinion poll of 1,000 Swiss citizens conducted in 2000 in the French- and Germanspeaking parts of the country showed that almost a third expressed a preference for English as the language of communication with the other linguistic regions; the percentage of persons who preferred either German or French is lower (Murray, Wegmüller \& Khan, 2000). Those results are reported in Table 3.

Age and geographical distance from the language border had an influence on respondents' language preferences. The younger generation is more likely to opt for English than the older generation, and those respondents living further away from the language border favoured English over the respective other national languages.

\section{Language Use and the Labour Market}

The perceived usefulness of English for professional purposes has increased in recent years, providing strong incentives to invest in the language. Whereas only international corporations and organisations 
TABLE 4

Use of selected languages at work percentages (1990 census figures)

\begin{tabular}{lcclcc}
\hline & French & Italian & $\begin{array}{l}\text { (Standard) } \\
\text { German }\end{array}$ & $\begin{array}{l}\text { Swiss } \\
\text { German } \\
\text { dialect(s) }\end{array}$ & English \\
& & & & 4.6 & 11.6 \\
\hline French speakers $^{\mathrm{a}}$ & 96.9 & 5.0 & 11.2 & 6.7 & 6.0 \\
Italian speakers $^{\mathrm{a}}$ & 16.2 & 89.4 & 14.1 & 91.4 & 18.5 \\
German speakers $^{\mathrm{a}}$ & 20.1 & 9.2 & 37.2 & 91.4 \\
\hline
\end{tabular}

${ }^{a}$ Within respective language region.

Source: Lüdi, Werlen and Franceschini (1997: 659).

used to require their employees to be competent in English, circumstantial evidence suggests that an increasing number of large Swiss companies require English language skills (Stotz, 2001: 122). This perception dovetails with econometric estimates of the rates of return on English language skills across the country (Grin, 1999, 2001a). These estimates are, to our knowledge, the only ones available anywhere in the world for a country in which English is neither an official language (e.g. Canada) nor the country's main language (e.g. USA, Australia). Estimates controlling for other determinants of labour income (mainly education and years of work experience) indicate particularly high returns for English, although returns on competence for French (in German-speaking Switzerland) and German (in French-speaking Switzerland) are also high. Case studies (e.g. Stotz, 2001) document the importance of English in some major companies, particularly at managerial level.

Table 4 shows that German and English are used at work with similar frequency by French-speakers in the French-speaking part of the country. German-speakers in the German-speaking part of Switzerland use slightly more French than English at work. The low percentage of users of standard German in this region reflects the importance of Swiss German as the main language of work, while the use of standard German is restricted to communication with people (including non-Swiss native speakers of German) who do not speak or understand the dialect.

Language attitudes among the general public play a major part in patterns of language learning and language use. These attitudes are, at this time, not adequately documented. However, they tend to be based on informal beliefs, such as the apparently widespread notion that English is an easy language, or that it facilitates a more 
egalitarian interaction between speakers of different languages, because everyone would have to make a roughly identical effort to learn it. Spoken English plays a limited role at Swiss universities, since undergraduate lectures and seminars are normally held in the respective official language of the region. Students, however, are increasingly required to read specialist literature in English, and some graduate courses are taught in English. This trend appears to be stronger in the natural sciences than in the social sciences. Switzerland's National Science Foundation increasingly requests applications for funding to be made in English.

\section{English in Swiss Compulsory Schools: Recent Developments}

Whereas many cantons have now added English to the curriculum at the beginning of secondary school (usually 7 th grade), other cantons have introduced English at a much earlier age, namely, at primary school, and in some cases before another national language. Much in evidence, in particular, is a string of such reforms in the canton of Zurich, which owing to its demographic size and economic weight, plays a leading role in German-speaking Switzerland. This reform enjoys the backing of large tracts of the local public. However, the expansion in the teaching of English has also brought about structural difficulties (Moser, Rhyn \& Stamm, 2002). Three types of problems come to the fore: actual instruction, teacher training, and results.

First, some children seem to be overburdened by the addition of a language to the curriculum. This seems to affect in particular weaker students, or those who have another (usually immigrant) mother tongue, or those that come from underprivileged families. While speaking another language at home is not, per se, a disadvantage (Stern, 2002), this characteristic often coincides with a lower socioeconomic status; thus, the reform may risk heaping difficulties on the same children. Conversely, stronger students, as well as those who have access to English outside the school, often complain about the slow pace of instruction. Loss of motivation is the result in both cases. ${ }^{6}$ This raises the question of whether some of the weaker students should be allowed to forgo English classes, and if so, on what criteria this decision should be based. A variant of this overload

\footnotetext{
${ }^{6}$ However, postponing the introduction of English (or sticking to modest, even perfunctory teaching goals in the language) exposes the system to another risk, namely, that wealthy families send their children to private English lessons, thus driving a wedge between linguistic haves and have-nots.
} 
problem arises, somewhat paradoxically, for majority children, owing to the particular context of German/Swiss German diglossia in German-speaking Switzerland. Given the trend towards an increasing use of Alemannic dialects, children are said to have to struggle to master standard German (Moser, Rhyn \& Stamm, 2002: 28; Forster, 2002: 2). Therefore, early English or French in the curriculum would compound the difficulty.

Second, the need to increase sharply, within a very short time, the recruitment of suitably qualified English teachers is also proving to be a problem in itself. In some pilot projects, English has been introduced not merely as a subject, but as a medium of instruction. For example, about 1,000 children in the participating schools in the canton of Zurich have received instruction through the medium of English in daily 20-minute sequences as part of content and language integrated learning (CLIL) (Stotz \& Meuter, 2003: 87). While this might dampen the need for specialist English teachers, it suggests that ordinary primary school teachers (whose native language is German, and who were never trained to teach through another language) need to receive adequate accelerated training in English in order to be able to teach through it (Acklin Muji 2003: 95).

Third, results have not always been in keeping with expectations. This applies even to CLIL pilot projects. The scheme's shortcomings, however, have been blamed on the inadequacy of the amount of time allocated for the English "language shower": 20 minutes per day, or about $8 \%$ of total teaching time, does not create the conditions for the true immersion experience needed to simulate natural language acquisition.

\section{Language Policy Implications}

As explained above, there is broad consensus around increased presence of English in the curriculum; however, some aspects of its implementation are considered problematic. Most controversial is the fact that starting with the 2005-2006 school year, many Germanspeaking cantons will replace French by English as a first FL from 3rd or even 2nd grade on, while French will become a second FL, taught only from 5 th - or even 7 th - grade onward. Somewhat disingenuously, the cantons concerned justify their choice by invoking the important role that "languages" in general play in Switzerland, or by the notion that children easily learn a foreign language at an early age and are very motivated to learn English. Both arguments may 
justify the young age of introduction rather than the switching of preferences in favour of English (see CDIP/EDK, 2001a). Once these changes are implemented, less than half of the cantons (in the main, the three bilingual cantons, as well as all French- and Italianspeaking cantons) will keep teaching a national language before English.

Despite this enthusiastic endorsement of English as the first FL in much of German-speaking Switzerland, many voices (an apparent minority in German-speaking Switzerland, and an apparent majority in the rest of the country) are expressing concern that "first" might soon mean "main," and that "main" will soon afterwards mean "only." Opponents not only fear an ill-advised and uncontrolled drift towards an excessive presence of English in the social and educational landscape (see section "Relevance of Bilingual Education"), but deleterious effects on national unity as well. The issue is therefore turning into one of political responsibility, namely, whether it is appropriate, given Switzerland's very specific history and linguistic and political structure, to give priority to English over national languages. Critics of the trend towards an increased effort to teach and learn English deride the purely market-oriented approach to language education policy that allegedly underpins this trend. They often argue that this amounts to a reckless omission of the cultural relevance and political import of Switzerland's national languages (e.g. Baschera, 1997).

A more widespread concern is that neglect of Switzerland's national languages may, in the long run, fatally undermine the country's uniqueness and unity. Apart from its mythical construction as a multilingual "imagined community" (Anderson, 1991; Grin, 2002), Switzerland has always defined itself by its very difference from the surrounding countries. One of the features that makes a western, French-speaking Swiss different from a Frenchman is his or her modicum of familiarity with the Germanic world; this access (and the ensuing difference) is a direct product of sharing the Swiss adventure with German-speaking fellow citizens. In the same way, what sets the German-speaking Swiss so clearly apart from their German neighbours is not only the increasing use of Alemannic dialects, but also their connection with the Latin world, which is ingrained through regular contact with French- and Italian-speaking fellow Swiss. Therefore, should these reciprocal contacts be further weakened through neglect (or through an overly enthusiastic endorsement of English), the very future of Switzerland as a "nation of the will" could be endangered. 
At the same time, the issue of inter-community contacts may be said to be virtual rather than factual, since neither language skills in the national languages, nor actual inter-regional contacts are as developed as is usually deemed politically desirable. It is unclear whether intra-Swiss contacts really suffer due to failing language skills, ${ }^{7}$ or if the relative lack of contact simply reflects a low interest in the other linguistic regions. Debate goes on as to how serious intercommunity indifference really is, or whether respective interests are, indeed, more divergent than before (Büchi, 2000).

Some commentators argue that the use of English as a lingua franca does not give rise, within the Swiss context, to harmful asymmetries (Coray, 2001: 173), whereas it does, by contrast, in the EU, because some citizens, being native English speakers, enjoy massive financial transfers (Grin, 2004). Therefore, Switzerland's language choices are tied with the much weightier debate on the preservation of multilingualism in Europe: if Switzerland were to endorse, in quasi-official manner, a lingua franca role for English, it would, despite its reputation as an exemplary stronghold of multilingualism, prove a less reliable model than the European Union, which keeps issuing documents on the necessity to celebrate and promote diversity (Commission européenne, 2003; Parlement Européen, 2004).

Finally, the debate over the role of English ties in with longstanding concerns about the marginalisation of Italian (Bianconi, 1994), and the increasingly desperate position of Romantsch (Furer, 1994). There have been no clear statements from the federal authorities on language issues, and the draft law intended to give substance to the new (and slightly more pro-active) constitutional provisions adopted by popular vote in 1996 has proved disappointingly devoid of analytical and political vision (Grin, 2001b).

To some extent, solutions to policy problems, or even major political ones described above, are sought on the pedagogical plane. Whether this is a sensible strategy is a question addressed in the following section.

\footnotetext{
${ }^{7}$ Studies at the end of the 1980s had shown that barely a quarter of Swiss were capable of communicating in any foreign language (Coray, 2001: 162); more recent survey figures (Grin, 1999) reveal an improvement in this respect. Therefore, the problem may lie not so much in the teaching and learning of national languages, as in foreign language skills in general.
} 


\section{Relevance of Bilingual Education}

Apart from teaching languages earlier (which increases the total time available for this purpose), new approaches to language instruction are seen as a key element in the enhancement of language teaching in general. In this section, we focus on bilingual education. Owing to limitations of space, "language awareness" programs (which have recently been introduced in a number of Swiss schools) as well as exchanges between language regions, (which play a marginal role in practice, despite a potentially important function) are not further discussed here. $^{8}$

Bilingual education here refers to the teaching of content through the medium of a FL. "Immersion" or CLIL is sometimes used synonymously for "bilingual education." There is little doubt that current interest for CLIL in Switzerland is influenced by the political context, and that policy makers are looking to language education specialists to get them out of a tight spot: If FLs can be successfully acquired through CLIL, then the conflict over resources (particularly teaching time) between different foreign languages becomes less. Advocates of this approach argue that it does not require additional English classes, while guaranteeing the maintenance of French as a second FL in the curriculum. This allows politicians to play to different constituencies, on one side by increasing the teaching of English, and on the other side by claiming that the teaching of national languages is not undermined. CLIL also is perfectly compatible with the teaching and learning of a second FL at a later stage, as required by cantonal school curricula.

Interest in CLIL, however, is not just the result of political calculation and did exist well before the pilot schemes discussed in the preceding section. Different types of bilingual education models using French, English, German, or Romantsch were developed in different language regions during the 1980s. The bilingual canton of Valais and the trilingual canton of Graubünden have introduced pilot groups in pre-school and primary education (German-French and RomantshGerman, respectively). Other models introduce bilingual education at secondary level after several years of traditional L2 instruction and prepare students for a bilingual graduation certificate. Evaluations of the different Swiss approaches have shown that properly

\footnotetext{
${ }^{8}$ The (still modest) development of language awareness programmes is supposed to defuse other potential tensions, and to help ease the transition into a more multicultural society.
} 
implemented bilingual education is a promising alternative to traditional language teaching with regard to language skills, while student achievement in the subjects taught through the medium of the L2 is generally not lower than in traditional classrooms. At secondary level, as little as $25 \%$ of immersion time in L2 leads to significant progress in second language acquisition (Diehl, 2001: 102; Grin \& Schwob, 2002).

CLIL does not, unfortunately, provide a ready-made solution to Switzerland's language problems. Some limitations have already been noted with respect to early English through CLIL in Zurich (see above); this dovetails with the evaluation results of a CLIL experiment in French-speaking Switzerland, where children received half of their instruction through German for a period of eight consecutive years. Evaluation results indicate that as a strategy for the initial stages of foreign language teaching, CLIL generates less sweeping effects than could have been expected, and that its effectiveness is highly sensitive to a number of factors, particularly whether it is offered to high- or medium-achievement children (Demierre-Wagner $\&$ Schwob, 2004). Additional socio-psychological and sociolinguistic issues arise. In some bilingual regions, a linguistic group - usually in the minority nationally, even if they are part of the local majority may feel threatened by the increased presence of the national majority language in the school curriculum, and the existence of such fears must be taken into account in policy formulation.

Another question arises, particularly in pre-school situations, when French-speaking children undergo immersion in German together with their (Alemannic) dialect-speaking peers. Should immersion prioritise standard German or dialect? While SwissGerman dialect is closer to children's speech habits in Germanspeaking Switzerland (and therefore represents a more "natural" learning environment), its acquisition as an FL creates a need for an additional learning effort at a later stage, once the francophone children start learning standard German. The use of standard German, by contrast, brings the children immediately closer to the demands of German classes at school, but it is impossible to establish it as the language of communication between Alemannic dialect speakers and French speakers, since it is foreign to both.

Finally, CLIL provides no answer to the essentially political question of the order in which languages should be taught; for reasons discussed earlier, rather more than mere pedagogical issues must be engaged when tackling this question. 


\section{CONCLuSion}

This overview of foreign language education in Switzerland and of the associated interplay of political and educational factors can only highlight some essential trends and features. For almost two centuries, Switzerland has managed its linguistic diversity in a way that has proved, in international comparison, remarkably successful. This arrangement is currently being challenged for a number of reasons that combine domestic and imported features. One of the most significant may well be the growing importance of English, which threatens to upset the delicate balance maintained until now through a consensual approach to second language education.

Some cantons, while advocating changes such as the introduction of English as a subject for all children, have been trying to do so within the traditional framework of a clear priority for Switzerland's national languages. Other cantons, however, seem to have been content with preserving, at best, the outward appearance of consensus. Closer examination reveals the extent of the challenges that the country is presently facing. Attempts are being made to de-politicise the issues at hand by stressing their educational or even technical aspects and denying their essentially political character. In particular, the development of CLIL is expected to take some of the edge off the competition for resources, particularly student time, between English and national languages.

It is now becoming increasingly difficult to paper over the cracks in the traditional consensus. Cantons will have to live up to the incontrovertibly political nature of their choices in language education policy. Despite its reputation as a boring country, Switzerland is likely to offer very interesting developments for students of language policy during the next few years.

\section{REFERENCES}

Acklin Muji, Dunya (2003). Le débat suisse des langues étrangères. Vers une réflexion sur l'auto-constitution du collectif helvétique. In Bulletin suisse de linguistique appliquée, 77, (pp. 67-81). Neuchâtel: University of Neuchatel.

Aeberli, Christian (2001). Englisch ab der ersten Klasse: Das Züricher Experiment. In Richard J. Watts \& Heather Murray (Eds), Die fünfte Landessprache? Englisch in der Schweiz (pp. 69-84). Zürich: Hochschulverlag.

Anderson, Benedict (1991). Imagined communities. London: Verso.

Baschera, Marco (1997) Wieviel Englisch erträgt die Schweiz? Neue Zürcher Zeitung, 11-12 October, 1997.

Bianconi, Sandro (1994). L'Italiano in Svizzera. Bellinzona: Osservatorio Linguistico della Svizzera Italiana. 
Büchi, Christoph (2000). Röstigraben. Das Verhältnis zwischen deutscher und französischer Schweiz. Geschichte und Perspektiven. Zürich: NZZ Verlag.

De Pietro, Jean-François (1994). Une variable négligée: les attitudes. Education et recherche, Vol. 1, (pp. 89-112). Fribourg: Univeritätsverlag.

CDIP/EDK (1998). Sprachenkonzept Schweiz. Retrieved from http://www.romsem. unibas.ch/sprachenkonzept/Konzept.html on January 26, 2004.

CDIP/EDK (2001a). Grobkonzept English an der Primarschule Retrieved from http:// www.bildungsplanung-zentral.ch/uploads/Englisch_PS_Konzept.pdf on January 26, 2004.

CDIP/EDK (2001b). Empfehlungen zur Koordination des Sprachenunterrichts in der obligatorischen Schule. Bern: Author.

CIIP (2003). Déclaration de la CIIP relative à la politique de l'enseignement des langues en Suisse romande. Neuchâtel: Author.

Commission européenne (2003). Promouvoir l'apprentissage des langues et la diversité linguistique: un plan d'action 2004-2006. Retrieved from http://europa.eu.int/ comm/education/doc/official/keydoc/actlang/act_lang_fr.pdf on March 15, 2004.

Coray, Renata (2001). English in der Schweiz: Trojanisches Pferd oder Sprungbrett für die Zukunft. In Richard J. Watts \& Heather Murray (Eds), Die fünfte Landessprache? Englisch in der Schweiz (pp. 161-179). Zürich: Hochschulverlag.

Demierre-Wagner, Andrea \& Schwob, Irène (2004). Évaluation de l'enseignement bilingue en Valais. Rapport final. Neuchâtel: Institut de Recherche et de Documentation Pédagogique.

Diehl, Erika (2001). Wie sag ich's meinem Kinde? Modelle des Fremdsprachenunterrichts in der Primarschule am Beispiel Deutsch im Wallis und Genf. In Kirsten Adamzik \& Helen Christen (Eds), Sprachkontakt, Sprachvergleich, Sprachvariation. Tübingen: Niemeyer.

Forster, Simone (2002, November). De quelques éclairages sur l'histoire de l'enseignement des langues. Bulletin CIIP, 10, 2-3.

Froidevaux, Didier (1997). Construction de la nation et pluralisme suisses: idéologie et pratiques. Revue suisse de science politique, 3, 29-58.

Furer, Jean-Jacques (1994). Vous avez dit frontière linguistique romanche-allemand? Babylonia, 94(2), 44-55.

Grin, François (1999). Compétences et récompenses: la valeur des langues en Suisse. Editions Universitaires Fribourg/Suisse.

Grin, François (2001a). English as economic value: facts and fallacies. World Englishes, 20(1), 65-78.

Grin, François (2001b). L'avant-projet de loi sur les langues et la compréhension: il reste du chemin à parcourir. Babylonia, 4(1), 26-27.

Grin, François (2002). La Suisse comme non-multination. In Michel Seymour (Ed), États-nations, multinations et organisations supranationales (pp. 265-281). Montréal: Liber.

Grin, François (2004). On the costs of linguistic diversity. In Ph. Van Parijs (Ed), Cultural diversity versus economic solidarity (pp. 93-206). Bruxelles: de BoeckUniversité.

Grin, François, Dagmar Hexel \& Irène Schwob (2003). Language Diversity and Language Education: an Introduction to the Swiss Model. In Theo du Plessis, Pol Cuvelier and Lut Teck (Eds), Multilingualism, education and social integration (pp. 86-98). Pretoria: Van Schaik Publishers. 
Grin, François \& Schwob, Irène (2002). Bilingual Education and Linguistic Governance: the Swiss experience. Intercultural Education, 13(4), 409-426.

Haas, Walter (1985). Histoire linguistique de la Suisse. In Robert Schläpfer (Ed), La Suisse aux quatre langues (pp. 21-64). Genève: Zoé. [First published in German as Die viersprachige Schweiz, Zürich: Benziger, 1982; reprinted in 2000.]

Lüdi, Georges, Iwar Werlen, Rita Franceschini, Francesca Antonini, Sandro Bianconi, Jean-Jacques Furer, Christine Quiroga-Blaser \& Adrian Wymann (1997). Die Sprachenlandschaft Schweiz. Bern: Bundesamt für Statistik.

Moser, Urs, Heinz Rhyn \& Margrit Stamm, (2002). Evaluation Englischobligatorium auf der Sekundarstufe I im Kanton Zürich. Retrieved from http:// www.bildungsdirektion.ch/internet/bi/de/publikationen/studien/evaluationen. SubContainerList. SubContainer1.ContentContainerList.0006.DownloadFile.pdf on October 5, 2003.

Murray, Heather, Wegmüller, Ursula \& Khan Fayaz Ali (2000). Englisch in der Schweiz. Forschungsbericht. Retrieved from http://www.bbw.admin.ch/html/pages/ services/publikationen/bildung/english-d.pdf on September 15, 2003.

Office fédéral de la statistique (2002). Population résidente selon la langue principale avec au moins 600 locuteurs. Berne: OFS. Retrieved from http://www. statistique.admin.ch/stat_ch/ber00/vz/cc/fvz-cc-spr-02.htm on September 15, 2003.

Ogay, Tania (2000). De la compétence à la dynamique interculturelle. Peter Lang, Bern.

Parlement Européen (2004). Préservation et promotion de la diversité culturelle [provisional version, 14 January 2004], P5_TA-PROV(2004)0022.

Stern, Otto (2002). Wissenschaftliches Gutachten über den teilweise gleichzeitigen Erwerb mehrerer Sprachen in der Primarschule. Zürich: Pädagogische Hochschule.

Stotz, Daniel (2001). Sprachenpolitik und Sprachpraxis in "big business": Der Status des Englischen. In Richard J. Watts \& Heather Murray (Eds), Die fünfte Landessprache? Englisch in der Schweiz (pp. 121-138). Zürich: Hochschulverlag.

Stotz, Daniel \& Teresa Meuter (2003). Embedded English: Integrating content and langue learning in a Swiss primary school project. Bulletin Suisse de Linguistique Appliquée, 77, 83-101.

Watts, Richard J. \& Heather Murray (Eds) (2001). Die fünfte Landessprache? Englisch in der Schweiz. Zürich: Hochschulverlag.

FRANÇOIS GRIN

School of Translation and

Interpretation (ETI)

University of Geneva

$\&$

Department of Education

Education Research Unit (SRED)

12 Quai du Rhône

1205 Genève

Switzerland

E-mail:francois.grin@etat.ge.ch
BRITTA KORTH

Department of Education

Education Research Unit (SRED)

12 Quai du Rhône

1205 Genève

Switzerland 